\title{
Telaah Kritis Penarikan dan Penempatan Pegawai dalam Perusahaan
}

\author{
Sunarta \\ Fakultas Ekonomi Universitas Negeri Yogyakarta \\ email :sunarta@uny.ac.id
}

\begin{abstract}
Abstrak
Artikel ini membahas studi literatur tentang proses penarikan dan penempatan pegawai dalam praktek Manajemen Sumber Daya Manusia. Penarikan pegawai merupakan program yang biasa dilakukan untuk memperoleh calon pegawai yang memenuhi kualifikasi untuk mengisi formasi jabatan dalam suatu organisasi atau perusahaan. Kebutuhan pegawai dapat dipenuhi dari internal maupun eksternal organisasi. Pemenuhan kebutuhan pegawai dari internal yaitu penarikan yang berasal dari dalam lingkungan organisasi, sedangkan pemenuhan kebutuhan pegawai dari eksternal yaitu proses penarikan yang bersumber dari luar organisasi. Sumber penarikan pegawai baik dari internal maupun eksternal, masing-masing mempunyai kelebihan dan kekurangan. Penarikan yang bersumber dari internal memiliki kelebihan dalam hal kecepatan beradaptasi dengan lingkungan kerja baru, mengenal, dan memahami tentang budaya kerja yang dianut serta digunakan sebagai norma bersama. Sebagai suatu model, penarikan yang bersumber dari eksternal akan sangat cocok dalam membangun budaya baru, mengantisipasi perubahan, dan implementasi berbagai program pengembangan organisasi.
\end{abstract}

Kata kunci: penarikan pegawai, sumber penarikan, penempatan.

\begin{abstract}
The article discusses the literature study on the recruitment and placement process of employees in Human Resource Management practice. Employee withdrawal is a program commonly used to obtain qualified prospective employees to fill job formations in an organization or company. Employee needs can be met from both internal and external to the organization. Fulfilling the needs of employees from internal, namely withdrawals originating from within the organization, while meeting the needs of external employees is the process of withdrawing originating from outside the organization. Sources of employee withdrawal, both internal and external, each have their own strengths and weaknesses. Withdrawals that come from internal sources that have advantages in terms of the speed of adapting to a new work environment, knowing, and understanding about the work culture that is adopted and is used as a common norm. As a model, external sources of withdrawal will be very suitable in building a new culture, anticipating change, and implementing various organizational development programs.
\end{abstract}

Keywords: employee withdrawal, source of withdrawal, placement.

\section{PENDAHULUAN}

Rekrutmen dan seleksi pegawai merupakan program yang biasa dilakukan organisasi atau perusahaan dalam memperoleh pegawai yang memenuhi kualifikasi yang diperlukan dalam mengisi formasi jabatan yang kosong (Ashraf, 2017; Schuler, 1987; Zhao \& Liden, 2011). Rekrutmen juga merupakan serangkaian aktivitas memikat/menarik pelamar kerja dengan motivasi, kemampuan, keahlian, dan pengetahuan yang diperlukan untuk menutupi kekurangan yang diidentifikasi dalam perencanaan kepegawaian (Zhao \& Liden, 2011). Penarikan pegawai merupakan suatu tahap lanjutan dari program perencanaan Sumber Daya Manusia (SDM), begitu juga tahap perencanaan SDM adalah sebagai bagian dari proses makro manajemen SDM yang 
menghasilkan desain-spesifikasi jabatan yang berfungsi sebagai panduan dalam melakukan penarikan pegawai dari aspek kuantitas maupun kualitas (Zhao \& Liden, 2011).

Secara kuantitas, proses penarikan akan berhasil apabila jumlah calon pelamar yang mendaftar bisa terpenuhi sesuai kebutuhan yang diinginkan (Saviour et al., 2016). Demikian pula proses penarikan pegawai pada periode tertentu akan dianggap berhasil apabila secara kualitas bisa mengisi beberapa formasi jabatan yang kosong sesuai dengan kualifikasi dan keahlian yang diinginkan. Dari sisi kebijakan strategis manajemen SDM, keberhasilan proses penarikan pegawai baru bisa dilihat dari hasil penilaian kinerja para pegawai yang diterima tersebut dalam menjalankan tugas pokok dan fungsinya selama periode tertentu.

Penarikan dan seleksi merupakan fase krusial dalam praktek manajemen SDM sehingga jika terjadi kesalahan dalam proses tersebut akan merugikan perusahaan baik jangka pendek maupun jangka panjang (Saviour et al., 2016; Syed \& Jamal, 2012). Kebijakan rekrutmen dianggap berhasil apabila jumlah dan kualifikasi yang dimiliki pelamar sesuai kebutuhan sehingga jika lolos seleksi/diterima di masa datang akan dapat membantu meningkatkan kinerja baik secara individu maupun organisasi.

Metode yang digunakan untuk mendapatkan calon pegawai yang diinginkan umumnya menggunakan dua sumber pasokan, yaitu dari internal dan eksternal organisasi (Bayo-Moriones \& Ortín-Ángel, 2006; Bhuyan, 2016; Bidwell, 2011; Devaro \& Kauhanen, Antti \& Valmari, 2019). Namun demikian tidak jarang beberapa perusahaan ada yang menggunakan metode gabungan, yakni sumber pasokan dari internal dan eksternal. Jika dilihat dari aspek strategi, maka dari tiga sumber pasokan calon pegawai tersebut masing-masing memiliki kelebihan dan kekurangan. Permasalahn yang muncul kemudian adalah, metode manakah yang paling tepat untuk digunakan sehingga dampak negatifnya minimal dan sebaliknya dapat memberikan sumbangan manfaat yang jauh lebih optimal bagi organisasi.

Setiap pilihan sebagai buah dari serangkaian proses keputusan dalam organisasi, terutama yang berorientasi bisnis tentu menyadari bahwa pilihan dalam setiap strategi akan membawa kosekuensi logis yang harus dihadapi. Dalam konteks proses penarikan pegawai, banyak organisasi bisnis yang keliru dalam mengambil keputusan antara mengadopsi perekrutan yang bersumber dari internal sendiri, eksternal, atau gabungan keduanya. Literatur review ini akan mengupas dan mengkritisi dari tiap metode, sehingga dapat digunakan sebagai rujukan dalam proses penarikan pegawai.

\section{TINJAUAN PUSTAKA}

\section{Proses Penarikan}

Sebagai sebuah rangkaian panjang, sebenarnya proses penarikan didasarkan dari hasil perencanaan SDM yang dilakukan sebelumnya yang telah menghasilkan informasi tentang kuantitas dan kualitas SDM yang dibutuhkan (Zhao \& Liden, 2011). Begitu pula tahap perencanaan SDM sendiri juga bersandarkan pada tahap sebelumnya yaitu analisis jabatan yang telah menghasilkan apa yang disebut sebagai deskripsi dan spesifikasi jabatan. Analisis jabatan merupakan salah satu pilar penting dalam praktik penarikan dan seleksi calon pegawai bagi organisasi. Semua tahapan tersebut berjalan sebagai bagian dalam rangka implementasi dari strategi bisnis yang dirancang sebelumnya oleh organisasi.

Setiap tahap praktik manajemen SDM saling berkaitan satu sama lain sehingga tidak dapat dipisahkan antara tahap satu dengan yang lain karena jika satu tahapan dilakukan, maka akan berpengaruh pada tahap yang lain begitu seterusnya. Satu tahapan praktik manajemen SDM yang tidak meggunakan prosedur yang jelas dan baku akan berdampak buruk terhadap hasil yang dicapai. Terdapat beberapa masalah yang menyebabkan keputusan pekerjaan yang buruk, yaitu ketidaktahuan dalam perencanaan sehingga pegawai yang diperoleh kurang baik (Zhao \& Liden, 2011). Dengan demikian penting bagi manajer SDM untuk membuat perencanaan SDM yang baik sehingga meningkatkan standar kualitas calon pelamar (Ashraf, 2017). Mengenai ruang 
lingkup dan kaitannya dengan penarikan sebagai bagian dari kegiatan manajemen SDM, dapat dilihat pada Gambar 1.

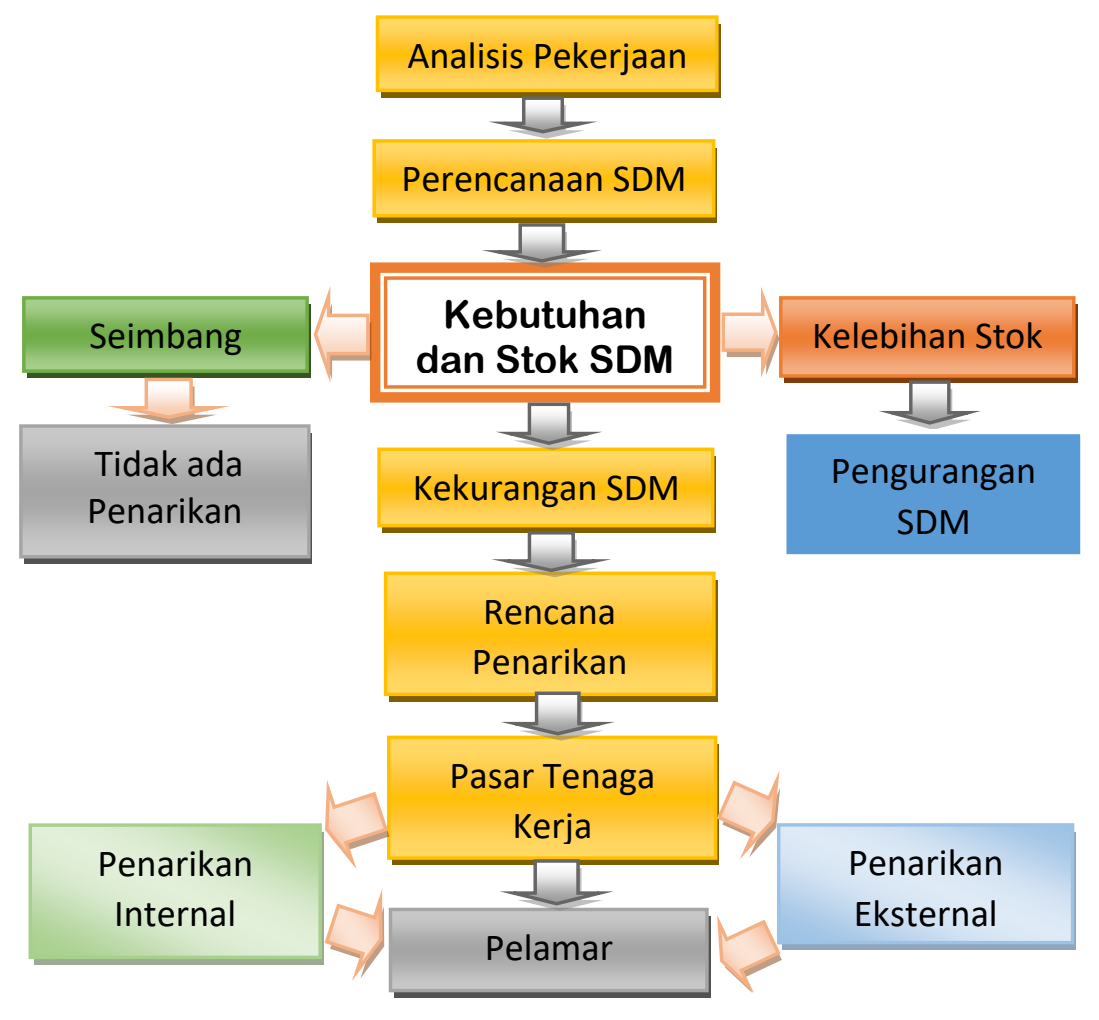

Gambar 1: Alur Proses Penarikan

Sumber: Modifikasi dari berbagai literatur

Seperti yang ditunjukkan pada Gambar 1, bahwa untuk mendapatkan calon pegawai yang diinginkan, manajer SDM khususnya dalam proses penarikan umumnya menggunakan dua sumber pasokan yaitu internal dan eksternal (Bayo-Moriones \& Ortín-Ángel, 2006; Bhuyan, 2016; Bidwell, 2011; Devaro \& Kauhanen, Antti \& Valmari, 2019). Jika dilihat dari aspek strategi, maka dari dua sumber pasokan tenaga kerja tersebut masing-masing memiliki kelebihan dan kekurangan. Dua sumber penarikan tersebut secara berganitan akan dibahas dan saling dikomparasikan satu sama lain sehingga memperoleh perspektif baru sebagai barikut.

\section{Sumber Internal}

Berbasis Resource Based View (Barney, 1991), sumberdaya manusia yang unik dan bernilai merupakan sumberdaya penting untuk kinerja dan keunggulan kompetitif (Lepak \& Snell, 1999). Pengembangan internal diperlukan untuk pengembangan kompetensi yang unik dan berharga yang dikembangkan melalui budaya organisasi. Setiap organisasi memiliki budaya yang berbeda (Lepak \& Snell, 1999). Pasokan yang bersumber dari internal tentu akan mudah dan cepat beradaptasi dengan lingkungan kerja baru karena telah lama mengenal dan memahami budaya kerja yang dianut dan digunakan sebagai norma bersama.

Pasokan eksternal diperlukan untuk adopsi pengetahuan baru dan pengembangan budaya baru karena lingkungan organisasi mengalami perubahan (Lepak \& Snell, 1999). Jika dilihat dari aspek motivasi kerja dan kedisiplinan, sumber pasokan pegawai dari eksternal mungkin akan sedikit menguntungkan organisasi, karena pegawai baru secara umum akan menunjukkan berbagai kemampuan yang membentuk citra diri (personal image) sehingga akan lebih produktif 
dan mudah dikendalikan. Tentu saja sumber pasokan dari keduanya memiliki kelebihan dan kekurangan masing-masing, sehingga keputusan apapun yang dijalankan organisasi pasti akan memiliki ekses dan resiko yang muncul.

Sumber penarikan pegawai dari internal adalah penarikan calon pengisi formasi kosong yang berasal dari dalam lingkungan organisasi. Kebijakan penarikan dari dalam biasanya dilakukan oleh organisasi yang sudah mapan dan profesional sehingga dalam proses mendapatkan calon pegawai yang diproyeksikan menduduki jabatan/pekerjaan tertentu sudah tertuang dalam peta karier pegawai (road map of personil career) dalam setiap periodenya. Melalui peta karier yang dimiliki, seorang manajer SDM dengan cepat dan mudah dapat menghitung berapa formasi yang kosong dan berapa jumlah ketersediaan pegawai yang memiliki kinerja baik untuk dipromosikan. Semakin banyak jumlah pegawai yang pantas untuk dinominasikan, maka semakin banyak alternatif pilihan yang bisa ditarik untuk mengisi lowongan yang kosong.

Penarikan dari dalam yang bersumber dari promosi atas prestasi dan berbagai capaian kinerja yang diraih oleh seorang pegawai, merupakan penghargaan yang pantas diberikan oleh organisasi. Namun demikian, kebijakan ini harus tetap menjunjung tinggi profesionalitas dan kualitias sehingga jauh dari sikap subjektif dari para perekrut yang diberi wewenang untuk memilih pegawai yang memiliki kapasitas dan kompetensi yang memadai di bidangnya masingmasing. Formasi kosong yang bisa diisi dari dalam secara tidak langsung dapat memperkuat komitmen individu, kelompok, dan organisasi dalam mendukung tercapainya tujuan bersama (Saviour et al., 2016).

Meningkatnya posisi jabatan yang diperloleh seseorang karena proses promosi akan menambah dan memperbaiki tingkat kesejahteraan. Kesejahteraan berupa gaji, upah, dan tunjangan lain yang diterima tentu juga akan memperkuat komitmen dan motivasi (Bidwell, 2011) dalam melaksanakan pekerjaan yang menjadi tanggung jawabnya. Sebaliknya, penarikan dari dalam kadang-kadang juga tidak membawa pengaruh peningkatan kinerja organisasi secara signifikan (Saviour et al., 2016). Hal ini terjadi karena pegawai yang dipromosikan mengisi formasi tertentu sedikit banyak telah mengenal budaya kerja dan model kepemimpinan yang diterapkan oleh pemimpinnya sehingga dapat mengurangi kewibawaan bagi pemimpin yang ada di atasnya.

Penarikan pegawai yang bersumber dari dalam organisasi sendiri dinilai sangat cocok untuk organisasi yang mengembangkan budaya stabilitas tinggi dan cenderung resisten terhadap perubahan. Pegawai hasil penarikan dari dalam pada umumnya memiliki motivasi kerja yang tinggi, loyal, dan komit terhadap nilai-nilai organisasi. Namun demikian tidak bisa dipungkiri bahwa pegawai dengan latar belakang dan kepentingan yang berbeda-beda sangat berpotensi memunculkan persaingan yang tidak sehat sehingga dalam seara pelan tapi pasti hal tersebut dapat menimbulkan konflik organisasi.

\section{Sumber Eksternal}

Model penarikan yang banyak digunakan oleh para penyelenggara peanarikan calon pegawai juga bisa berasal dari eksternal organisasi. Sumber penarikan pegawai dari eksternal adalah proses memperoleh calon pegawai yang berasal dari pasar tenaga kerja diluar organisasi yang membutuhkan. Sumber-sumber eksternal yang bisa menyediakan pasokan calon pegawai antara lain perguruan tinggi, balai latihan kerja, agen tenaga kerja, organisasi profesi, famili pegawai dalam organisasi, iklan pada media cetak dan elektronik (Devaro \& Kauhanen, Antti \& Valmari, 2019).

Penggunaan model penarikan eksternal memiliki beberapa kelebihan antara lain, jumlah pelamar yang banyak akan memberikan pilihan alternatif yang sangat kompetitif sehingga calon yang lolos di tahap penarikan dan seleksi merupakan orang-orang pilihan terbaik, (Bayo- 
Moriones \& Ortín-Ángel, 2006; Devaro \& Kauhanen, Antti \& Valmari, 2019). Selain itu, sumber eksternal juga mengurangi anggapan subjektivitas dan hallo efect antara pelamar dengan penguji.

Beberapa kemungkinan yang muncul dari kelemahan penarikan sumber eksternal adalah para pelamar yang akhirnya diterima sebagai pegawai masih awam terhadap peralatan dan lingkungan kerja sehingga berpotensi mengalami kecelakaan kerja atau penggunaan waktu kerja yang terlalu lama sehingga terkesan tidak efisien. Pegawai baru yang belum mengenal seluk beluk lingkungan seringkalai sangat mudah dipengaruhi oleh teman kerja yang lebih senior (Moser, 2005) sehingga hal tersebut akan berpengaruh terhadap komitmen dan motivasi kerja pegawai. Secara dikotomis, beberapa kelebihan dan kelemahan dari kedua model yang sering digunakan oleh banyak organisasi dapat dilihat pada tabel sebagai berikut.

Tabel 1: Kelebihan dan Kelemahan

Metode Penarikan Sumber Internal dan Eksternal

\begin{tabular}{|c|c|}
\hline Sumber Internal & Sumber Eksternal \\
\hline $\begin{array}{l}\text { - Karyawan termotivasi dalam bekerja } \\
\text { - Karyawan lebih menghargai waktu } \\
\text { kerja } \\
\text { - Peluang promosi besar } \\
\text { - Meningkatkan loyalitas karyawan } \\
\text { - Meningkatkan moral kerja dan } \\
\text { komitmen } \\
\text { - Wawasan dan pengetahuan karyawan } \\
\text { - } \text { Pempit } \\
\text { mersaingan yang tidak sehat akan } \\
\text { menimbulkan konflik organisasi }\end{array}$ & $\begin{array}{l}\text { - Melahirkan ide, konsep, wawasan baru } \\
\text { - Relatif mudah untuk melakukan } \\
\text { perubahan } \\
\text { - Struktur, sistem, dan hirarki organisasi } \\
\text { tidak mengalami perubahan yang } \\
\text { signifikan } \\
\text { - Karyawan baru membutuhkan } \\
\text { bimbingan dan latihan kerja-butuh } \\
\text { waktu lama } \\
\text { - Peluang promosi semakin sempit } \\
\text { - Karyawan baru perlu waktu } \\
\text { menyesuaikan dengan budaya yang } \\
\text { dianut. }\end{array}$ \\
\hline
\end{tabular}

Sumber: Dihimpun dari berbagai literatur.

Tabel 1 mengkonfirmasi bahwa dari kedua metode penarikan baik internal maupun eksternal saling memiliki kelebihan dan kekurangan masing-masing. Secara dikotomik dapat dijelaskan bahwa sumber penarikan internal akan lebih cocok untuk organisasi bisnis yang mapan dan kurang adaptif terhadap perubahan lingkungan eksternal. Sementara sumber penarikan eksternal sangat cocok untuk jenis organisasi yang responsif terhadap perubahan lingkungan bisnis yang berkembang. Organisasi bisnis yang memiliki komitmen tinggu untuk selalu menjadi yang terdepan disbanding pesaing, sangat cocok mengadopsi sumber eksternal. Pegawai baru yang terseleksi akan memiliki motivasi yang tinggi mengikuti tujuan organisasi karena belum terkontaminasi budaya negatif pegawai seperti bermalas-malas, menunda pekerjaan, dan memicu keonaran yang merugikan atau mengganggu lingkungan kerja.

Sebagai bentuk antisipasi adanya beberapa kelemahan terhadap pemilihan sumber pasokan (internal dan eksternal), dimungkinkan alternatif penarikan campuran (mix) antara keduanya. Model campuran eksternal dan internal berguna untuk mengisi jabatan tertentu yang tidak bisa diisi dari luar atau dari dalam karena beberapa alasan khusus sesuai karakter jabatan dan kerahasiaan jabatan yang kosong (Bayo-Moriones \& Ortín-Ángel, 2006; Bhuyan, 2016; Devaro \& Kauhanen, Antti \& Valmari, 2019). Mempertimbangkan berbagai jenis jabatan dalam organisasi yang memiliki kekhasan dan syarat yang hanya bisa dipenuhi oleh sedikit orang profesional, maka model campuran internal dan eksternal dapat menjadi salah satu pilihan sehingga dampak negatif dari program penarikan pegawai dapat diminimalisir.

Model penarikan campuran lainnya yang bisa menjadi alternatif solusi dalam program penarikan adalah dengan cara menjaring dan menyeleksi karyawan yang sedang menjalankan 
magang untuk memenuhi kebutuhan staf organisasi secara strategis. Dalan lingkungan bisnis yang kompetitif, memerlukan SDM yang memiliki keunggulan bersaing yang tinggi, terbuka terhadap perubahan, kreatif, dan inovatif. Dengan adanya tuntutan lingkungan bisnis tersebut, organisasi sebagai pengguna tenaga kerja harus berpikir terbuka dan menerima kreativitas para magang dan mendorong magang untuk kritis, mau mengungkapkan gagasan, pikirannya sehingga mereka merasa diharagai (Zhao \& Liden, 2011)

Penarikan untuk mendapatkan calon pegawai yang diinginkan merupakan aktivitas yang biasa dilakukan oleh bagian manajeman SDM dalam suatu organisasi. Setelah melalui tahap rekrutmen, ada tiga tahap penting yang dijalankan dalam memperoleh pegawai yang tepat untuk pekerjaan yang tepat pula. Proses pertama seleksi (selection), kedua orientasi (orientation), dan ketiga adalah penempatan (placement). Tahap pelaksanaan orietasi atau pengenalan kepada lingkungan kerja dan tahap penempatan sebenarnya dapat dilakukan secara bersamaan atau secara terpisah. Semua sangat tergantung dari kebiasaan dan prosedur yang dianut dan digunakan oleh masing-masing organisasi. Dengan kata lain, tidak ada yang salah dalam proses orientasi dan penempatan dengan cara terpisah atau satu rangkaian kegiatan secara bersamaan.

\section{PEMBAHASAN}

\section{Alasan dan Tujuan Seleksi}

Salah satu alasan yang mendasar dilakukannya proses seleksi dalam sebuah organisasi adalah karena adanya jabatan yang telah, sedang, dan akan kosong dalam waktu tertentu. Hanya dengan melakukan seleksi inilah organisasi akan memperoleh banyak pilihan alternatif dalam memilih calon pegawai yang sesuai dengan formasi. Kemudian salah satu tujuan seleksi adalah untuk memperoleh calon pegawai sesuai jumlah dan kualifikasi yang diinginkan untuk mengisi formasi jabatan yang kosong. Kekosongan jabatan dalam suatu organisasi dapat terjadi karena beberapa alasan, antara lain karena memasuki batas usia pensiun pegawai, meninggal dunia, keluar/pindah kerja, karena rotasi atau rangkap jabatan, demosi, dan karena promosi atau menduduki jabatan yang lebih tinggi sebagai penghargaan atas prestasi yang dicapainya (Schuler, 1987; Zhao \& Liden, 2011).

Dengan menggunakan beberapa alasan tersebut, maka organisasi yang ingin maju dan berkembang dalam mewujudkan visi, misi, tujuan, dan strategi yang dibangun bersama, menjadi nafas bersama bagi semua elemen organisasi, maka proses seleksi pegawai menjadi kewajiban terutama bagi manajer SDM. Begitu penting dan strategisnya tahapan penarikan sebagai salah satu fungsi manajemen SDM dan merupakan salah satu kegiatan yang berdampak paling kritis terhadap kinerja sebuah organisasi (Saviour et al., 2016), Begitu penting dan strategisnya proses seleksi karena dalam jangka panjang masa depan organisasi akan ditentukan oleh para pegawai baru hasil seleksi. Kajian-kajian empiris telah membuktikan bahwa ada korelasi positif dan penting antara rekrutmen dan seleksi terhadap kinerja perusahaan (Gamage, 2014; Saviour et al., 2016) dan kinerja bisnis (Gilani \& Jamshed, 2016; Hauser, 2011). Proses rekrutmen dan seleksi memang sangat menentukan masa depan organisasi, bahkan penerapan rekrutmen dan proses seleksi yang efektif berhubungan erat dengan organisasi (Syed \& Jamal, 2012).

Penarikan dan seleksi adalah proses menarik individu secara tepat waktu dalam jumlah yang cukup dan dengan kualifikasi yang sesuai, untuk mengisi posisi dalam struktur organisasi (Bayo-Moriones \& Ortín-Ángel, 2006; Devaro \& Kauhanen, Antti \& Valmari, 2019). Penarikan dan seleksi juga bisa dilihat sebagai sebuah proses dalam upaya menghasilkan/menyediakan sekelompok pelamar/kandidat yang cukup agar manajer dapat memilih karyawan yang dibutuhkan, yang memenuhi syarat untuk lowongan pekerjaan organisasi (Saviour et al., 2016). Seleksi merupakan proses pemilihan dari sekelompok pelamar yang paling memenuhi kriteria seleksi untuk posisi yang tersedia di dalam perusahaan (Ashraf, 2017; Bhuyan, 2016; Saviour et al., 2016). 
Jika dilihat dari sisi jumlah, maka semakin banyak pelamar/kandidat yang memenuhi syarat untuk mengikuti seleksi dengan sendirinya akan semakin panjang waktu yang dibutuhkan dan biayanya juga semakin besar. Dari sisi kualitas semakin banyak pelamar yang masuk, maka hal itu akan semakin baik karena pilihan dan alternatif untuk memperoleh pegawai yang benar-benar diinginkan memiliki banyak pilihan. Melimpahnya jumlah pelamar walaupun dari sisi biaya akan sedikit membebani organisasi, tetapi hal itu menunjukkan tingginya minat dan kesungguhan pelamar untuk bergabung dengan organisasi. Besarnya biaya akibat jumlah pelamar yang banyak hanyalah pertimbangan teknis (paradigm lama), sehingga pada tataran akademis harus dilihat bahwa banyaknya calon pegawai yang melamar justeru sebagai tantangan (paradigma baru) dalam melihat masa depan organisasi di masa datang.

\section{Paradigma Baru}

Seiring perkembangan dan tuntutan bisnis yang kompetitif, saat ini telah terjadi perubahan paradigma atas pelaksamaan proses penarikan dan seleksi pegawai (Ployhart, 2006). Mendaftar jumlah pelamar yang masuk, melakukan ujian tertulis, prkatik, wawancara, dan beberapa bentuk tes keterampilan lainnya merupakan paradigma lama yang telah mengalami pergeseran isi dan keluasan cakupan materi seleksi. Paradigma baru menganggap bahwa untuk menjawab perubahan lingkungan bisnis yang kompetitif, maka tenaga kerja harus dipandang sebagai kunci pertumbuhan bisnis, tidak sekedar terjebak proses penarikan, wawancara calon, dan mengisi lowongan (Phillips \& Gully, 2015; Saviour et al., 2016), yang bersifat administratif.

Penggunaan paradigma baru dalam proses penarikan dan seleksi pegawai digunakan sebagai tonggak (milestone) dalam merencanakan dan menjawab tantangan perubahan serta persaingan bisnis yang semakin keras. Penarikan dan pemilihan pegawai sangat mahal, baik dari segi waktu dan anggaran sehingga prosesnya perlu dilakukan secara efektif dan efisien sehingga hasil pengangkatan seseorang sesuai dengan pekerjaan yang sedang atau akan ditempati (Phillips \& Gully, 2015; Saviour et al., 2016). Perekrutan dan seleksi merupakan bagian yang mahal dan vital dalam pencapaian bisnis (Bhuyan, 2016). Mahalnya biaya proses penarikan sangat signifikan ketika beberapa pegawai yang diseleksi dan dinyatakan diterima ternyata akhirnya keluar karena berbagai alasan seperti upah, kepemimpinan, budaya kerja, keamanan kerja, dan faktor lainnya yang kadang-kadang bersifat sangat subjektif. Keluarnya pegawai hasil seleksi yang mahal dalam organisasi sangat merugikan baik dari sisi waktu dan anggaran.

Serangkaian tahapan waktu yang panjang untuk seleksi, penempatan, pelatihan, dan pengiriman berbagai jenis pelatihan-keterampilan dengan biaya besar yang dikeluarkan, organisasi ada kalanya harus menerima kenyataan dan merelakan bagi pegawai tertentu untuk keluar kerja dengan alasan yang kadang sulit duterima. Keadaan yang lebih menyedihkan ketika pegawai yang telah dididik dan dikembangkan sehingga memiliki keahlian tertentu harus keluar/dibajak oleh perusahaan lain karena alasan gaji/upah dan kesejahteraan lainnya yang lebih baik daripada sebelumnya. Sebagai antisipasi atas kejadian tersebut, penting bagi organisasi bahwa dalam usaha untuk terus bersaing dan secara tepat mampu mengenali dan memperkirakan kebutuhan SDM yang diinginkan. Hal yang tidak kalah pentingnya adalah melihat dan mempertimbangkan tren masa lalu, menganalisis situasi sekarang, dan memperkirakan SDM yang diperlukan untuk memenuhi persyaratan rencana strategis organisasi (Ashraf, 2017).

\section{Instrumen Seleksi}

Merujuk pada tujuan dilakukannya seleksi, yakni untuk memperoleh calon tenaga kerja atau pegawai sesuai kuantitas dan kualitas yang diinginkan untuk mengisi formasi jabatan yang kosong, maka untuk merealisasikannya perlu ditempuh beberapa tahapan dan prosedur yang harus dipenuhi. Untuk mendapatkan pegawai yang memiliki kompetensi dan kapasitas memadai sesuai yang diinginkan, harus melalui proses seleksi yang sangat ketat dan panjang. Hal ini menyangkut waktu, tempat, penguji/pengetes, metode dan teknik apa yang akan digunakan 
sehingga hasilnya objektif serta benar-benar memperoleh pegawai sesuai formasi yang diinginkan.

Metode seleksi pegawai yang digunakan oleh penyelenggara biasanya menggunakan jasa organisasi proefesional atau suatu Perguruan Tinggi yang telah memiliki naskah soal yang terstandar. Soal-soal tes yang digunakan untuk seleksi pegawai yang sudah standar pada umumnya memiliki tingkat validitas dan reliabilitas yang tinggi sehingga hasilnya dapat dipertanggungjawabkan secara ilmiah. Validitas menyangkut kehandalan/ketepatan alat (soal) sebagai instrumen yang digunakan, sedangkan reliabilitas menyangkut keajegan/konsistensi soal sebagai pengukur dalam menilai kemampuan seseorang.

Selain nilai tes tertulis yang standar (tes objektif) seperti di atas, ada beberapa bentuk tes lainnya yang biasa digunakan pula untuk seleksi pegawai yakni psiko-tes (kepribadian, kraeplien, logika aritmatik, penalaran dll.). Bentuk tes lain dalam seleksi pegawai dalam suatu organisasi juga ada yang bersifat subjektif seperti wawancara tentang kepribadian calon, orientasi pekerjaan, pengalaman masa lalu, proyeksi masa depan, toleransi, kerjasama, besaran gaji, dan kondisi ekonomi orang tua. Dari hasil penilaian tetulis, psiko tes, dan wawancara akan diperoleh nilai akumulasi sehingga secara objektif yang memiliki nilai paling tinggi akan dinyatakan "diterima" untuk mengisi formasi yang kosong sesuai kebutuhan.

\section{Orientasi}

Program orientasi merupakan tahap lanjutan dari tahap seleksi yang menghasilkan sekumpulan SDM pilihan yang unggul sesuai formasi dalam suatu organisasi. Orientasi merupakan sebuah upaya yang dilakukan oleh para pelamar yang dinyatakan lolos seleksi dan diterima sebagai pegawai untuk mengenal lebih dekat mengenai berbagai hal seperti struktur organisasi, ruang lingkup kerja, iklim kerja, peralatan kerja, dan keselamatan kerja (Schuler, 1987; Zhao \& Liden, 2011). Kegiatan orientasi sangat penting bagi para pegawai baru yang akan bekerja mengisi formasi yang kosong sesuai kebutuhan. Pada masa orientasi ini pegawai baru melakukan sosialisasi dengan para pegawai senior dan pimpinan di tiap-tiap bagian/divisi sehingga terjalin keakraban dan saling mengenal satu sama lain sampai akhirnya bergabung menjadi team work yang kuat dalam naungan organisasi yang sama.

Selain untuk bersosialisasi dan mengenal lebih dekat terhadap lingkungan kerja yang akan dimasuki, masa orientasi juga bertujuan untuk membantu bagi para pegawai baru dalam memahami prosedur kerja dan standar kerja yang harus dilakukan. Melalui kegiatan orientasi ini para pegawai baru juga memperoleh penjelasan tentang aspek teknis pekerjaan/jabatan yang akan diterima sehingga nantinya pada saat bekerja dapat berjalan dengan baik, efektif, efisien, dan menghasilkan kinerja yang optimal. Masa orientasi bagi para pegawai baru memiliki makna yang sangat strategis dan menentukan dalam perjalanan kariernya di masa datang. Kesalahan dan kegagalan dalam beradaptasi dengan lingkungan kerja yang akan dimasukinya, maka hal itu sebagai isyarat bagi dirinya dan organisasi di masa datang.

Selama menjalani masa orientasi, para pegawai baru tentunya ingin menjadi bagian dari para pegawai lama, tetapi ada kalanya dalam perjalanannya tidak jarang pegawai baru memperoleh perlakuan yang tidak menyenangkan. Hal ini tentunya harus disikapi dan dipandang sebagai ujian mental bagi para pegawai baru untuk bisa mengenal pola hubungan antar pegawai dan iklim kerja yang dikembangkan dalam organisasi tersebut. Harus disadari bahwa dalam organisasi banyak orang dengan berbagai karakter dan perilaku serta latar belakang budaya, etnis, pendidikan, ekonomi, suku, dan agama yang bermacam-macam. Kesadaran atas berbagai perbedaan yang ditemui di tempat kerja baru akan membentuk dan memperkaya wawasan, pengalaman, toleransi, dan saling menghargai satu sama lain.

Dalam menyelenggarakan masa orientasi, para manajer dan pimpinan organisasi harus bisa meyakinkan harapan-harapan dan target organisasi yang akan dicapai dalam kurun waktu tertentu. Melalui cara tersebut pegawai baru akan merasa memiliki kontrak secara psikologis antara pribadinya dengan pimpinan untuk mewujudkan apa yang menjadi tujuan organisasi. 
Keterbukaan informasi dari para manajer tentang berbagai hal yang berkaitan dengan pekerjaan akan mengurangi tingkat kesalahan dan kecelakaan yang mungkin dilakukan para pegawai baru pada saat bekerja. Pengenalan tentang apa yang menjadi visi, misi, tujuan, dan program organisasi juga sering menjadi bagian dari materi dalam masa orientasi pegawai baru. Keberhasilan dalam proses internalisasi visi dan misi organisasi dari para pegawai akan memperkuat komitmen, loyalitas, dan motivasi dalam setiap upaya menghasilkan kinerja optimal.

\section{Penempatan}

Kegiatan manajemen SDM yang ketiga dari proses penarikan pegawai setelah tahap seleksi dan orientasi/sosialisasi adalah tahap penempatan pegawai (personil placement). Penempatan adalah penugasan kepada para pelamar yang dinyatakan diterima pada suatu jabatan yang kosong sesuai formasi yang ditawarkan sebelumnya. Pada tahap ini akan diuji tingkat kesesuaian antara kemampuan dan keahlian yang dimiliki oleh pegawai. Calon hasil rekrutmen dan berbagai rangkaian proses seleksi yang dinyatakan diterima, kemudian ditempatkan pada posisi yang ditawarkan, sehingga sejak saat itu kepada pegawai tersebut telah melekat tugas, wewenang, dan tanggung jawab yang harus dipikul dan dipertanggung jawabkan kepada pimpinan di atasnya.

Kesenjangan (gap) antara persyaratan yang tertuang dalam formasi dengan kemampuan yang dimiliki oleh pegawai yang diterima akan menjadi legitimasi tingkat keberhasilan dan profesionalitas proses penarikan pegawai. Ketidaksesuaian dan rendahnya kemampuan pegawai dalam beradaptasi dan mewujudkan berbagai tujuan yang telah ditetapkan sebelumnya, maka hal ini makin mempertegas rendahnya kompetensi yang dimiliki sebagai akibat buruknya model penarikan dan seleksi yang diterapkan oleh organisasi tersebut. Sebaliknya jika ternyata pegawai baru yang menempati formasi yang kosong dapat menjawab tuntutan sesuai yang diharapkan selama ini, maka hal itu membuktikan bahwa proses penarikan berjalan dengan baik dan menghasilkan pegawai terpilih yang handal, cakap, kompeten, dan kapabel untuk bekerja secara efektif dan efisien (Vipin et al., 2017).

Sebagai tahap akhir dari serangkaian proses penarikan, tahap penempatan pegawai ini merupakan legitimasi keberhasilan atau kegagalan kegiatan penarikan secara keseluruhan bagi manajer SDM khsusnya dan organisasi secara umum. Dengan kata lain tahap ini merupakan tahap evaluasi atas proses penarikan pegawai yang dirancang dan dilaksanakan dengan melibatkan berbagai pihak, dengan mengalokasikan anggaran, waktu, tenaga, dan pikiran. Semua penggunaan alokasi sumber daya yang ada untuk pelaksanaan kegiatan penarikan pegawai akan terbayar manakala menghasilkan pegawai yang mampu memegang amanah, cakap dalam menjalankan tugas pokok dan fungsinya, memiliki integritas, kapasitas, kapabilitas dalam mewujudkan visi, misi, serta tujuan organisasi.

\section{KESIMPULAN}

1. Kekosongan jabatan dalam suatu organisasi dapat terjadi karena beberapa faktor seperti batas usia pensiun pegawai, meninggal dunia, keluar/pindah kerja, rotasi atau rangkap jabatan, demosi, dan promosi.

2. Penarikan adalah proses rutin untuk mendapatkan calon pegawai yang diinginkan dalam rangka mengisi kekosongan jabatan tertentu guna kelangsungan organisasi di masa yang akan datang melalui tiga tahap yaitu, rekrutmen, seleksi, dan orientasi/penempatan.

3. Untuk memperoleh pegawai sesuai formasi, dapat dilakukan dengan cara penarikan yang bersumber dari internal organisasi sendiri, eksternal, dan atau gabungan dari keduanya.

4. Organisasi bisnis yang sudah mapan dan cenderung resisten terhadap perubahan lebih cocok menggunakan metode penarikan yang bersumber dari dalam organisasi sendiri.

5. Organisasi bisnis yang terus berinovasi dan selalu beradaptasi dengan lingkungan eksternal dalam penarikan pegawai lebih cocok menggunakan metode penarikan yang bersumber dari eksternal. 


\section{DAFTAR PUSTAKA}

Ashraf, J. (2017). Examining the Public Sector Recruitment and Selection, in Relation to Job Analysis in Pakistan. Social Sciences, 3 (1), 1309134. https://doi.org/10.1080/23311886.2017.1309134.

Barney, J. (1991). Firm resources and sustained competitive advantage. Journal of Management, 17, 99-129. https://doi.org/10.1177/014920639101700108

Bayo-Moriones, A., \& Ortín-Ángel, P. (2006). Internal Promotion Versus External Recruitment: Industrial Plants in Spain. Industrial \& Labor Relations Review, 59 (3), 451-470. https://doi.org/10.1177/001979390605900307

Bhuyan, S. . (2016). A Study of Recruitment Source and Selection Process in the Public and Private Universities in Banglades. Global Journal of Management and Business Research: A Administration and Management, 6 (8), 515-526.

Bidwell, M. (2011). Paying More to Get Less: The Effects of External Hiring Versus Internal Mobility. Administrative Science Quarterly, $56 \quad$ (3), 369-407. https://doi.org/10.1177/0001839211433562

Devaro, J., \& Kauhanen, Antti \& Valmari, N. (2019). Internal and External Hiring. Industrial \& Labor Relations Review, XX(X), 1-28. https://doi.org/10.1177/0019793919842810

Gamage, A. (2014). J Recruitment and Selection Practices in Manufacturing SMEs in Japan: An analysis of the link with business performance. Sri Lankan Journal of Human Resource Management, 1, 49-57.

Gilani, H., \& Jamshed, S. (2016). An exploratory study on the impact of recruitment process outsourcing on employer branding of an organisation. Strategic Outsourcing: An International Journal, 9, 303-323. https://doi.org/10.1108/SO-08-2015-0020

Hauser, S. G. (2011). Recruitment outsourcing is the wave of the present. Workforce Management, 1 (2), 12.

Lepak, D. P., \& Snell, S. A. (1999). The Human Resource Architecture: Toward a Theory of Human Capital Allocation and Development. Academy of Management Review, 24 (1), 3148. https://doi.org/10.5465/amr.1999.1580439

Moser, K. (2005). Recruitment Sources and Post-Hire Outcomes: The Mediating Role of Unmet Expectations. International Journal of Selection and Assessment, 13 (3), 188-197. https://doi.org/10.1111/j.1468-2389.2005.00314.x.

Phillips, J., \& Gully, S. (2015). Multilevel and Strategic Recruiting: Where Have We Been, Where Can We Go From Here? Journal of Management, XX(X), 1-30. https://doi.org/10.1177/0149206315582248

Ployhart, R. (2006). Staffing in the 21st Century: New Challenges and Strategic Opportunities. Journal of Management, 32, 868-897. https://doi.org/10.1177/0149206306293625

Saviour, A. W., Kofi, A., Yao, B. D., \& Kafui, L. . (2016). The Impact of Effective Recruitment and Selection Practice on Organisational Performance: A Case Study at University of 
Ghana. Global Journal of Management and Business Research: A Administration and Management, 16(11), 24-33.

Schuler, R. S. (1987). Personnel and Human Resources Management. New York University: Kelogg Borkvard.

Syed, Z., \& Jamal, W. (2012). Universalistic Perspective of HRM and Organisational Performance: Meta-Analytical Study. International Bulletin Of Business Administration, 13, 1451-243.

Vipin, Nadda, V., Raq, Z., \& Tyagi, P. (2017). Efectiveness and Challenges of Recruitment Process Outsourcing (RPO) in the Indian Hotel Sector.

Zhao, H., \& Liden, R. C. (2011). Internship: A Recruitment and Selection Perspective. Journal of Applied Psychology, 96(1), 221-229. https://doi.org/10.1037/a0021295 